\title{
Influence of Eating Habits and Physical Activity on Body Mass Index of Female Nursing Students
}

\author{
Dr.Thilagavathi Krishnasamy ${ }^{1}$, Divya Raju ${ }^{2}$, Eman Mahmoud ${ }^{3}$, \\ ${ }^{1}$ Lecturer in Obstetrics and Gynecology Nursing, College of Nursing and Allied Health Sciences, Jazan \\ University, Ministry of education, Kingdom of Saudi Arabia. \\ ${ }^{2}$ Lecturer in Community Health Nursing, College of Nursing and Allied Health Sciences, Jazan University, \\ Ministry of education, Kingdom of Saudi Arabia. \\ ${ }^{3}$ Lecturer in Obstetrics and Gynecology Nursing, College of Nursing and Allied Health Sciences, Jazan \\ University, Ministry of education, Kingdom of Saudi Arabia.
}

\begin{abstract}
Life style changes in Saudi Arabia over recent decades made major impact on food habits and physical activity of individuals. Overweight and obesity are emerging epidemic affecting large proportion of population especially adolescents. This paper aims to find the influence of eating habits and physical activity on body mass index of female nursing students. A descriptive study was conducted in College of Nursing and Allied Health Sciences, Jazan University among one hundred and twenty eight female nursing students. Demographic Performa and Self-administered questionnaire on eating habits and physical activity were used to collect the data. Individual subject height and weight were measured to calculate body mass index. Majority (36.7\%) of them were in 20 years. Nearly half of students (50.8\%) had family history of chronic illness in which $38.1 \%$ of family members suffered with diabetes. About $12.5 \%$ of them experienced irregular menstrual cycles. Level of body mass index revealed $18.7 \%$ were obese, while $18 \%$ were overweight, $38.3 \%$ were normal and $25 \%$ were underweight. Frequency of consuming restaurant food, fast foods, chocolates, juices and carbonated drinks was much higher as compared to intake of vegetables and fruits in a day or over a week. More than one third of subjects (36.7\%) were not involved in any form of physical activity. Association between level of body mass index with their eating habits and physical activity had statistical significance ( $p>0.05)$ only for portion size of meals taken. The present study findings suggest educational programme has to be tailored to create awareness on healthy eating habits and physical activity among adolescents to prevent prevalence of non-communicable disease in future.
\end{abstract}

Keywords: Eating habits; Physical activity; Body Mass Index (BMI); Overweight; Obesity.

\section{Introduction}

Obesity is an alarming non communicable disease affecting large proportion of population around the world. World health Organization reports globally obesity has more than doubled since 1980[1]. 2.1 billion People - nearly $30 \%$ of the world's population - are either obese or overweight, according to a new, first-of-its kind analysis of trend data from 188 countries [2]. In 2014, data revealed 39\% of adults aged 18 years and over were overweight and $13 \%$ were obese. Most of the world's populations live in countries where overweight and obesity kills more people than underweight [1].

Over the 33-year period of research, the Middle East showed large increases in obesity. Bahrain, Egypt, Saudi Arabia, Oman, and Kuwait were among the countries with the largest increases in obesity globally [2]. Recently Lancet (2016) reported that KSA is in the third position in the world, after Malta and Swaziland, in terms of obesity [3]. The rapid cultural and social changes that have occurred in the Arabian Gulf region, since the discovery of oil and the economic boom during the 1970's and 1980's, were associated with an alarming increase in obesity [4-8]. One of the major causes of obesity is the changes in the diet, in terms of quantity and quality, which has become more "Westernized" [9]. Recent studies revealed increasing consumption of animal products and refined foods in the diet at the expense of vegetables and fruits [10-11]. These dietary changes were accused for increasing the prevalence of both overweight and obesity observed among Saudi children, adolescences and adults in the last few decades [12-15].The fundamental cause of obesity and overweight is an energy imbalance between calories consumed and calories expended. Globally, there has been: an increased intake of energy-dense foods that are high in fat; and an increase in physical inactivity due to the increasingly sedentary nature of many forms of work, changing modes of transportation, and increasing urbanization [16]. Raised BMI is a major risk factor for non-communicable diseases such as: cardiovascular diseases, which were the leading cause of death in 2012; diabetes; musculoskeletal disorders; some cancers (including endometrial, breast, ovarian, prostate, liver, gallbladder, kidney, and colon).College students are highly exposed to unhealthy eating habits leading to body weight gain [17]. In KSA, Rasheed et al [18] documented that $30.6 \%$ of female health college students were either overweight or obese. 
Aim: This study aims to find the influence of eating habits and physical activity on body mass index of female nursing students.

\section{Research objectives}

1. To assess the level of body mass index (BMI) of female nursing students.

2. To assess frequency of eating habits and physical activity of female nursing students.

3. To find association between level of body mass index (BMI) with their eating habits and physical activity of female nursing students.

\section{Methodology}

Adopting descriptive design, the present study was undertaken in College of nursing and Allied Health Sciences, Jazan University, Kingdom of Saudi Arabia. Formal permission was obtained from concerned authorities to conduct the study. Students studying in second year $(\mathrm{N}=128)$ were chosen by convenience sampling. Nature and objectives of the study was explained to them, followed by oral consent was obtained. Further they were assured on privacy and confidentiality of data collected. Demographic performa and selfadministered questionnaire on eating habits and physical activity were tools used for data collection. Demographic performa included subject's characteristics such as age, family health history and menstruation details. Self-administered questionnaire on eating habits and physical activity was prepared by the researchers based on literature support. This questionnaire had 8 items on eating habits and 5 items related to physical activity. Subjects were instructed to fill the questionnaire based on past week recall on eating habits and physical activity and specify no of times(1-2/3-4/5-6/7-8/more than 9 times) per day and per week. Followed by height and weight of each subject was measured and Body Mass Index (BMI) was calculated. Scores were interpreted based on WHO criteria for BMI,

$\begin{array}{lll}\text { Less than } 18.5 \mathrm{~kg} / \mathrm{cm}^{2} & - & \text { Underweight } \\ 18.5-24.99 \mathrm{~kg} / \mathrm{cm}^{2} & - & \text { Normal Range } \\ 25.0-29.99 \mathrm{~kg} / \mathrm{cm}^{2} & - & \text { Overweight (pre-obese) } \\ \text { More than } 30 \mathrm{~kg} / \mathrm{cm}^{2} & - & \text { Obesity. }\end{array}$

Collected data was coded and analyzed using SPSS software 20.0 based on the objectives of the study. Descriptive and inferential statistics were applied in analysis and findings were presented with tables and diagrams.

\section{Results}

Table 1: Demographic characteristics of subjects.

\begin{tabular}{|c|c|c|c|}
\hline S.No & Demographic characteristics & $\mathbf{F}$ & $\%$ \\
\hline 1. & $\begin{array}{l}\text { Age } \\
19 \text { years } \\
20 \text { years } \\
21 \text { years } \\
22 \text { years } \\
23 \text { years } \\
24 \text { years }\end{array}$ & $\begin{array}{l}19 \\
47 \\
32 \\
21 \\
05 \\
04\end{array}$ & $\begin{array}{l}14.8 \\
36.7 \\
25.0 \\
16.4 \\
03.9 \\
03.2\end{array}$ \\
\hline $\begin{array}{c}2 . \\
2(a) .\end{array}$ & $\begin{array}{l}\text { Family health history } \\
\text { Yes } \\
\text { No } \\
\text { Family chronic illness } \\
\text { Diabetes mellitus } \\
\text { Hypertension } \\
\text { Diabetes + Hypertension } \\
\text { Heart disease } \\
\text { Anaemia } \\
\text { Others }\end{array}$ & $\begin{array}{l}65 \\
63 \\
\\
24 \\
09 \\
18 \\
03 \\
08 \\
03\end{array}$ & $\begin{array}{l}50.8 \\
49.2 \\
\\
36.9 \\
13.8 \\
27.7 \\
04.6 \\
12.3 \\
04.6\end{array}$ \\
\hline 3. & $\begin{array}{l}\text { Age of Menarche } \\
10-11 \text { years } \\
12-13 \text { years } \\
14-15 \text { years }\end{array}$ & $\begin{array}{l}11 \\
77 \\
40\end{array}$ & $\begin{array}{l}08.6 \\
60.2 \\
31.2\end{array}$ \\
\hline 4. & $\begin{array}{l}\text { Pattern of menstrual cycles } \\
\text { a) Regular } \\
\text { b) Irregular }\end{array}$ & $\begin{array}{c}112 \\
16\end{array}$ & $\begin{array}{l}87.5 \\
12.5\end{array}$ \\
\hline
\end{tabular}

Table 1 shows, majority of subjects $47(36.7 \%)$ were belonged to 20 years. More than half of them, 65(50.8\%) had a family health history in which $24(36.9 \%)$ suffered with Diabetes Mellitus. Most of the girls $77(60.2 \%)$ have attained menarche at 12-13 years and few of them $16(12.5 \%)$ had irregular cycles. 


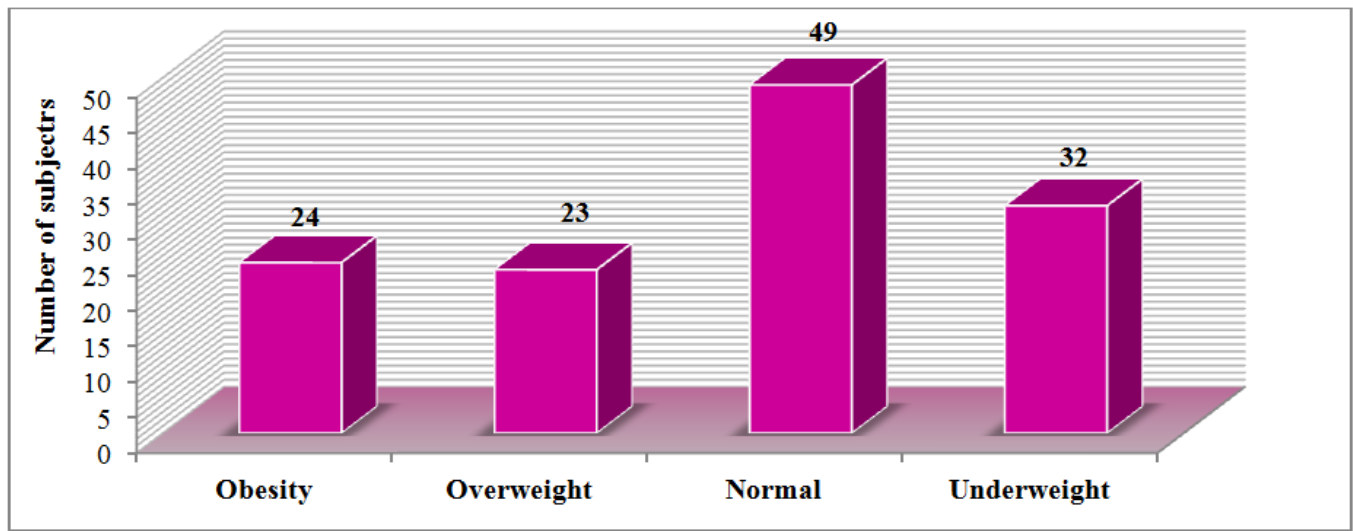

Figure 1: Level of Body Mass Index (BMI) among subjects.

Figure 1 depicts the percentage distribution of subjects based on level of body mass index. Nearly quarter of subjects $24(18.7 \%)$ were obese, $23(18 \%)$ of them was overweight, 49(38.3\%) maintained normal range and $32(25 \%)$ was underweight.

Table 2.1: Distribution of subjects based on taking food from restaurant, Eating fast food and chocolate intake.

\begin{tabular}{|c|c|c|c|c|c|c|c|c|c|c|c|c|c|}
\hline \multirow{3}{*}{$\begin{array}{l}\text { S. } \\
\text { n } \\
\text { o }\end{array}$} & \multirow[t]{3}{*}{$\begin{array}{l}\text { Frequency of } \\
\text { intake }\end{array}$} & \multicolumn{4}{|c|}{$\begin{array}{l}\text { Taking food } \\
\text { from Restaurant }\end{array}$} & \multicolumn{4}{|c|}{ Eating fast food } & \multicolumn{4}{|c|}{ Chocolates intake } \\
\hline & & \multicolumn{2}{|c|}{ / day } & \multicolumn{2}{|c|}{ /week } & \multicolumn{2}{|c|}{ / day } & \multicolumn{2}{|c|}{ /week } & \multicolumn{2}{|c|}{ / day } & \multicolumn{2}{|c|}{ /week } \\
\hline & & $\mathrm{F}$ & $\%$ & $\mathrm{~F}$ & $\%$ & $\mathrm{~F}$ & $\%$ & $\mathrm{~F}$ & $\%$ & $\mathrm{~F}$ & $\%$ & $\mathrm{~F}$ & $\%$ \\
\hline \multirow[t]{6}{*}{1.} & a)None & 31 & 24.2 & 12 & 9.4 & 08 & 6.2 & 0 & 0 & 28 & 21.8 & 04 & 3.1 \\
\hline & b)1-2 times & 88 & 68.7 & 31 & 24.2 & 89 & 69.5 & 0 & 0 & 76 & 59.4 & 10 & 7.8 \\
\hline & c)3-4 times & 07 & 5.5 & 19 & 14.8 & 21 & 12.4 & 07 & 5.5 & 19 & 14.9 & 16 & 12.5 \\
\hline & d)5-6 times & 02 & 1.6 & 09 & 7.0 & 05 & 3.9 & 13 & 10.1 & 05 & 3.9 & 03 & 2.3 \\
\hline & e)7-8 times & 0 & 0 & 41 & 32.0 & 05 & 3.0 & 61 & 47.6 & 0 & 0 & 49 & 38.4 \\
\hline & f) $>9$ times & 0 & 0 & 16 & 12.5 & 0 & 0 & 47 & 36.8 & 0 & 0 & 46 & 35.9 \\
\hline
\end{tabular}

Table 2.1 describes in regard to restaurant food intake, 88(68.7\%) of students taken 1-2 times a day and $41(32 \%)$ taken 7-8 times a week. For eating fast food (Fried potatoes, Lays, Doroto, Albatal) about 89(69.5\%) taken 1-2 times a day and 61(47.6\%) consumed 7-8 times a week. For chocolates intake, 76(59.4\%) taken 1-2 times a day and $49(38.4 \%)$ ate $7-8$ times per week.

Table 2.2: Distribution of subjects based on juices, vegetables and fruits intake.

\begin{tabular}{|c|c|c|c|c|c|c|c|c|c|c|c|c|c|}
\hline & & & & & & & & & & & $(\mathrm{N}=$ & & \\
\hline \multirow[t]{3}{*}{$\overline{\text { S.no }}$} & \multirow{3}{*}{$\begin{array}{c}\text { Frequency of } \\
\text { intake }\end{array}$} & \multicolumn{4}{|c|}{ Juices intake } & \multicolumn{4}{|c|}{ Eating vegetables } & \multicolumn{4}{|c|}{ Eating fruits } \\
\hline & & \multicolumn{2}{|c|}{ / day } & \multicolumn{2}{|c|}{ /week } & \multicolumn{2}{|c|}{ / day } & \multicolumn{2}{|c|}{ /week } & \multicolumn{2}{|c|}{ / day } & \multicolumn{2}{|c|}{ /week } \\
\hline & & $\mathrm{F}$ & $\%$ & $\mathrm{~F}$ & $\%$ & $\mathrm{~F}$ & $\%$ & $\mathrm{~F}$ & $\%$ & $\mathrm{~F}$ & $\%$ & $\mathrm{~F}$ & $\%$ \\
\hline \multirow[t]{6}{*}{1.} & a) None & 23 & 17.9 & 11 & 8.6 & 45 & 35.2 & 25 & 19.5 & 31 & 24.2 & 15 & 11.7 \\
\hline & b) 1-2 times & 75 & 58.7 & 05 & 3.9 & 69 & 53.9 & 06 & 4.7 & 78 & 60.9 & 10 & 7.8 \\
\hline & c) 3-4 times & 27 & 21.1 & 08 & 6.2 & 14 & 10.9 & 06 & 4.7 & 19 & 14.9 & 07 & 5.5 \\
\hline & d) 5-6 times & 03 & 2.3 & 03 & 2.3 & 0 & 0 & 08 & 6.2 & 0 & 0 & 76 & 59.3 \\
\hline & e) 7-8 times & 0 & 0 & 54 & 42.3 & 0 & 0 & 62 & 48.4 & 0 & 0 & 20 & 15.6 \\
\hline & f) $>9$ times & 0 & 0 & 47 & 36.7 & 0 & 0 & 21 & 16.5 & 0 & 0 & 0 & 0 \\
\hline
\end{tabular}

Table 2.2 shows majority $75(58.7 \%)$ of them taken juices 1-2 times a day and 54(42.3\%) drank 7-8 times a week. About 69(53.9\%) took vegetables 1-2 times a day and 62(48.4\%) consumed 7-8 times a week. For eating fruits $78(60.9 \%$ ) consumed 1-2 times a day and 76(59.3\%) taken 5-6 times a week.

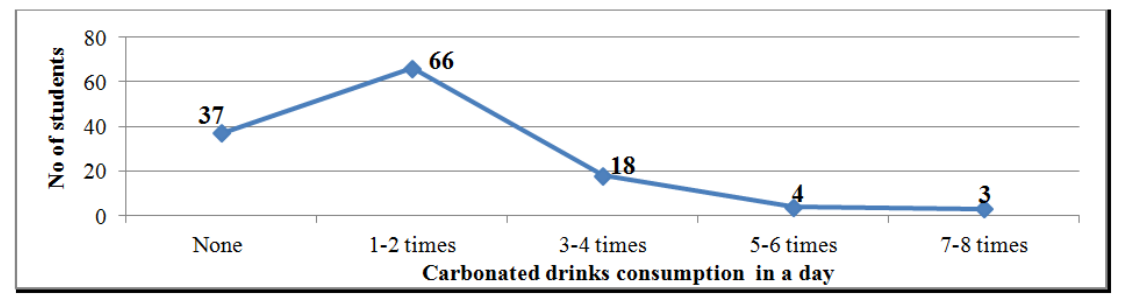

Figure 2: Frequency of consuming carbonated drinks in a day 


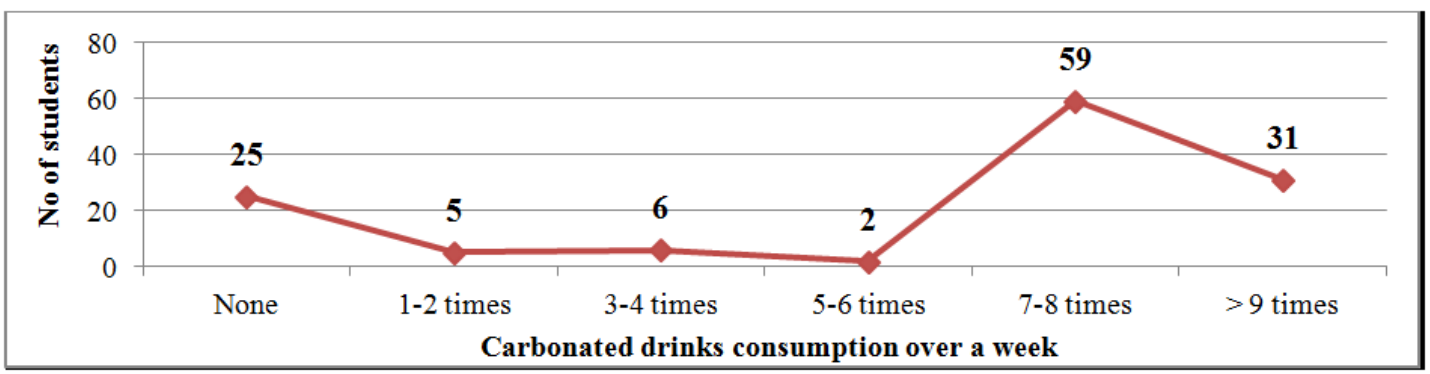

Figure 3: Frequency of consuming carbonated drinks in a week.

Figure 2 \& Figure 3 depicts majority (66) of subjects consumed carbonated drinks 1-2 times in a day and about (59) of them drank 7-8 times in a week.

Table 2.3: Distribution of subjects based on breakfast intake and portion size of meals consumed. $(\mathrm{N}=128)$

\begin{tabular}{|c|c|c|c|}
\hline S.No & Eating habits & $\mathbf{F}$ & $\%$ \\
\hline 1. & $\begin{array}{l}\text { Breakfast intake in a week } \\
\text { a) None } \\
\text { b) } 1 \text { day } \\
\text { c) } 2 \text { day } \\
\text { d) } 3 \text { day } \\
\text { e) } 4 \text { day } \\
\text { f) } 5 \text { day } \\
\text { g) } 6 \text { days } \\
\text { h) } 7 \text { days }\end{array}$ & $\begin{array}{l}05 \\
11 \\
15 \\
15 \\
12 \\
34 \\
05 \\
31\end{array}$ & $\begin{array}{c}3.9 \\
8.6 \\
11.7 \\
11.7 \\
9.4 \\
26.6 \\
3.9 \\
24.2\end{array}$ \\
\hline 2. & $\begin{array}{l}\text { Portion size of meals consumed } \\
\text { a) Never } \\
\text { b) Rarely } \\
\text { c) Occasionally } \\
\text { d) Sometimes } \\
\text { e) Always }\end{array}$ & $\begin{array}{l}19 \\
34 \\
27 \\
31 \\
17\end{array}$ & $\begin{array}{l}14.8 \\
26.6 \\
21.1 \\
24.2 \\
13.3\end{array}$ \\
\hline
\end{tabular}

Table 2.3 explains that $31(24.2 \%)$ have taken breakfast every day and very few $5(3.9 \%$ skipped it. While considering the portion size of meals, $17(13.3 \%)$ consumed always and 34(26.6\%) have taken it rarely.

Table 3: Frequency distribution of subjects based on physical activity.

$(\mathrm{N}=128)$

\begin{tabular}{|c|c|c|c|}
\hline S.No & Physical activity & $\mathbf{F}$ & $\%$ \\
\hline \multirow[t]{3}{*}{1.} & Physical activity at home & & \\
\hline & Yes & 81 & 63.3 \\
\hline & No & 47 & 36.7 \\
\hline \multirow[t]{7}{*}{2.} & Type of physical activity & & \\
\hline & Walking & 61 & 75.3 \\
\hline & Running in treadmill & 04 & 04.9 \\
\hline & Jogging & 04 & 04.9 \\
\hline & Swimming & 07 & 08.6 \\
\hline & Walking \& Running in treadmill & 03 & 03.7 \\
\hline & Walking \& Swimming & 02 & 02.5 \\
\hline \multirow{3}{*}{3.} & Frequency of physical activity in a day & & \\
\hline & Once a day & 55 & 67.9 \\
\hline & Twice a day & 26 & 32.1 \\
\hline \multirow[t]{3}{*}{4.} & Duration of physical activity in a day & & \\
\hline & 30 minutes & 71 & 87.6 \\
\hline & More than 30 minutes & 10 & 12.4 \\
\hline \multirow[t]{8}{*}{5.} & Number of days in a week performed physical activity & & \\
\hline & 1 & 14 & 17.3 \\
\hline & 2 & 24 & 29.6 \\
\hline & 3 & 16 & 19.7 \\
\hline & 4 & 8 & 09.9 \\
\hline & 5 & 7 & 08.6 \\
\hline & 6 & 4 & 04.9 \\
\hline & 7 & 8 & 09.9 \\
\hline
\end{tabular}

Table 3 describes, 81(63.3\%) of subjects were involved with physical activity in which, most of them 61(75.3\%) did walking. More than half of them 55(67.9\%) practiced once in a day for about 30 minutes $71(87.6 \%)$. Very few subjects $8(9.9 \%)$ performed physical activity every day. 
Table 4: Association between level of body mass index of subjects with their eating habits and physical activity.

\begin{tabular}{|c|c|c|c|c|c|c|c|}
\hline \multirow[t]{2}{*}{ S.No } & \multirow[t]{2}{*}{ Items } & \multicolumn{4}{|c|}{ Level of BMI } & \multirow[t]{2}{*}{$\chi^{2}$} & \multirow[t]{2}{*}{$\mathrm{p}$ value } \\
\hline & & Obesity & $\begin{array}{c}\text { Over } \\
\text { weight }\end{array}$ & Normal & $\begin{array}{c}\text { Under } \\
\text { weight }\end{array}$ & & \\
\hline \multirow[t]{17}{*}{1.} & Eating habits & & & & & & \\
\hline & a) Restaurant food intake in a day & 24 & 23 & 49 & 32 & 8.811 & 0.455 \\
\hline & b) Restaurant food intake in a week & 24 & 23 & 49 & 32 & 8.416 & 0.906 \\
\hline & c) Fast food intake in a day & 24 & 23 & 49 & 32 & 14.777 & 0.254 \\
\hline & d) Fast food intake in a week & 24 & 23 & 49 & 32 & 11.021 & 0.527 \\
\hline & e) Chocolates intake in a day & 24 & 23 & 49 & 32 & 3.640 & 0.933 \\
\hline & f) Chocolates intake in a week & 24 & 23 & 49 & 32 & 7.720 & 0.935 \\
\hline & g) Juice intake in a day & 24 & 23 & 49 & 32 & 7.752 & 0.559 \\
\hline & h) Juice intake in a week & 24 & 23 & 49 & 32 & 12.009 & 0.678 \\
\hline & i) Carbonated drinks intake in a day & 24 & 23 & 49 & 32 & 8.497 & 0.745 \\
\hline & j) Carbonated drinks intake in a week & 24 & 23 & 49 & 32 & 11.604 & 0.709 \\
\hline & k) Vegetables intake in a day & 24 & 23 & 49 & 32 & 5.341 & 0.501 \\
\hline & 1) Vegetables intake in a week & 24 & 23 & 49 & 32 & 12.350 & 0.652 \\
\hline & m) Fruits intake in a day & 24 & 23 & 49 & 32 & 3.809 & 0.703 \\
\hline & n) Fruits intake in a week & 24 & 23 & 49 & 32 & 12.290 & 0.423 \\
\hline & o) Breakfast intake in a week & 24 & 23 & 49 & 32 & 18.285 & 0.631 \\
\hline & p) Portion size of meals & 24 & 23 & 49 & 32 & 23.186 & $0.026 * * *$ \\
\hline \multirow[t]{6}{*}{2.} & Physical activity & & & & & & \\
\hline & a) Practice of physical activity & 24 & 23 & 49 & 32 & 2.154 & 0.541 \\
\hline & b) Kind of physical activity & 24 & 23 & 49 & 32 & 21.730 & 0.595 \\
\hline & c) Frequency of physical activity & 24 & 23 & 49 & 32 & 7.520 & 0.275 \\
\hline & d) Duration of physical activity & 24 & 23 & 49 & 32 & 3.773 & 0.707 \\
\hline & e) Physical activity over a week & 24 & 23 & 49 & 32 & 10.764 & 0.967 \\
\hline
\end{tabular}

Table 4 on association between level of body mass index with eating habits and physical activity of subjects showed statistical significance $(\mathrm{p}<0.05)$ only for portion size of meals in eating habits. Rest of the items it was not significant.

\section{Discussion}

The present study findings revealed out of 128 subjects, 24(21.1\%) were obese, while 23(15.6\%) were overweight, 49(38.3\%) were normal and 32(25\%) were underweight. From the numerical data it is well evident that there is a streamline of obesity, overweight and underweight prevailed among female nursing adults. Few subjects had more concern about their weight and body shape helped them to maintain normal weight. At the same time due to incorrect intake of nutrients and diet restriction resulted in underweight among quarter (25\%) of them. Above results were supported in a study conducted by King Saud University, Riyadh, KSA(2009) among three hundred and twelve students (180 females and 132 male) revealed a quarter of students was found to be overweight $(21 \%)$ or obese $(6.5 \%)$ respectively[19]. There are many factors that impact eating behaviors involved in consuming fast food. For example, increased portion size, snacking and night eating, low nutritional value, eating out, availability (24/7) and easy accesses, low price, entertainment, sedentary life, and marketing. Therefore, fast food restaurants play a leading role in increased calorie consumption among all age groups and genders, which may lead to overweight and obesity especially among children and adolescents

Daily frequency of eating from restaurant, fast food intake, chocolates intake, drinking Juice, vegetables and fruits intake was ranged from 1-2 times and 7-8 times weekly. It was also found that $35.2 \%$ on daily basis and $19.5 \%$ on weekly did not take any vegetables. Similarly $24.2 \%$ of them in a day and $11.7 \%$ in a week did not eat any fruits respectively. Several studies conducted in the Arab Gulf States indicated that fruit and vegetable consumption among children and youth is not sufficient, which can impact intake of important and essential nutrients [20].

Drinking carbonated drinks was much higher in majority of subjects which was (66) consumed at least 1-2 times in a day and 7-8 times (59) in a week respectively. Less than one third of subjects (24.2\%) took breakfast every day, $3.9 \%$ of them skipped breakfast and majority $(26.6 \%)$ consumed 5 days in a week. Reason for skipping breakfast could be lack of time and long travel hours to reach college. But this has direct effect on the attention power of students in the morning lecture and indirect impact on the academic performance. Davis et al. 2009 found that US urban children were more likely to skip breakfast [21]. In addition, in the United States and Europe, research has shown a large prevalence of breakfast skipping [22].

More than half of students $(63.3 \%)$ did not participate in any physical activity. Only $36.7 \%$ of subjects were involved with physical activity in which, most of them (75.3\%) did walking. More than half of them $(67.9 \%)$ practiced once in a day for about 30 minutes $(87.6 \%)$ respectively. In a week, only few subjects $8(9.9 \%)$ did a physical activity every day. Studies from other local data showed that physical inactivity was $60 \%$ in Saudi children and $70 \%$ of youth did not engage in health enhancing physical activity for sufficient duration 
and frequency [23-24]. Additionally, due to cultural factors and beliefs in Saudi Arabia, youth engagement in PA is not regarded as a desired pursuit. Families usually encourage their children toward academic excellence rather than physical activity [25].

\section{Conclusion}

Overweight and obesity are non-communicable diseases are largely preventable. Health educational programmes imparted at school level will help to create awareness about healthy eating habits and importance of physical activity among adolescents. Life style changes initiated from home level at early stage might eradicate obesity in future generation.

\section{Reference}

[1]. World Health Organization Statistics on obesity and overweight retrieved from http://www.who.int/mediacentre/factsheets/fs311/en/

[2]. Marie NG,Tom Fleming BS,Margaret Robinson BA, Nicholas Greetz BS, Christoper BS, Erin C,et al, Global, regional, and national prevalence of overweight and obesity in children and adults during 1980-2013: a systematic analysis for the Global Burden of Disease Study 2013. Lancet, Volume 384, No. 9945, p766-781, 30(8):2014.

[3]. KSA 3rd in world obesity ranking. Retrieved from http://www.arabnews.com/node/965551/saudi-arabia.

[4]. Musaiger AO, Al-Mannai MA. Weight, height, body mass index and prevalence of obesity among the adult population in Bahrain. Ann Hum Biol. 2001;28(3):346-350. doi: 10.1080/030144601300119151. [PubMed] [Cross Ref]

[5]. Al-Kandari YY. Prevalence of obesity in Kuwait and its relation to sociocultural variables. Obes Rev. 2006;7:147-154. doi: 10.1111/j.1467-789X.2006.00231.x. [PubMed] [Cross Ref]

[6]. Carter AO, Saadi HF, Reed RL, Dunn EV. Assessment of obesity, Lifestyle, and Reproductive Health Needs of Female Citizens of Al Ain, United Arab Emirates. J Health Popul Nutr. 2004;22(1):75-83. [PubMed]

[7]. Al-Riyami AA, Afifi MM. Prevalence and correlates of obesity and central obesity among Omani adults. Saudi Med J. 2003;24(6):641-646. [PubMed]

[8]. Alsaif MA, Hakim IA, Harris RB, Alduwaihy M, Al-Rubeaan K, Al-Nuaim AR, Al-Attas OS. Prevalence and risk factors of obesity and overweight in adult Saudi population. Nutr Res. 2002;22:1243-1252. doi: 10.1016/S0271-5317(02)00439-6.[Cross Ref]

[9]. Antonio G, Chiara PA. A Natural Diet Versus Modern Western Diets? A New Approach to Prevent "Well-Being Syndromes". Dig Dis Sci. 2005;50(1):1-6. doi: 10.1007/s10620-005-1268-y. [PubMed] [Cross Ref]

[10]. Amin TT, Al-Sultan AI, Ali A. Overweight and obesity and their relation to dietary habits and socio-demographic characteristics among male primary school children in Al-Hassa, Kingdom of Saudi Arabia. Eur J Nutr. 2008;47:310-318. doi: 10.1007/s00394008-0727-6. [PubMed] [Cross Ref]

[11]. Mahfouz AA, Abdelmoneim I, Khan MY, Daffalla AA, Diab MM, Al-Gelban KS, Moussa H. Obesity and Related Behaviors among Adolescent School Boys in Abha City, Southwestern Saudi Arabia. J Trop Pediatr. 2007;54(2):120-124. doi: 10.1093/tropej/fmm089. [PubMed] [Cross Ref]

[12]. Al-Nuaim AA, Bamgboye EA, Al-Rubeaan KA, Al-Mazrou Y. Overweight and Obesity in Saudi Arabian Adult Population, Role of Sociodemographic Variables. J Community Health. 1997;22(3):211-223. doi: 10.1023/A:1025177108996. [PubMed][Cross Ref]

[13]. Al-Nozha MM, Al-Mazrou YY, Al-Maatouq MA, Arafah MR, Khalil MZ, Khan NB, Al-Marzouki K, Abdullah MA, Al-Khadra AH, Al-Harthi SS, Al-Shahid MS, Al-Mobeireek A, Nouh MS. Obesity in Saudi Arabia. Saudi Med J. 2005;26(5):824829. [PubMed]

[14]. Al-Hazzaa HM. Rising trends in BMI of Saudi adolescents: evidence from three national cross sectional studies. Asia Pac J Clin Nutr. 2007;16(3):462-466. [PubMed]

[15]. El-Hazmi MA, Warsy AS. A Comparative Study of Prevalence of Overweight and Obesity in Children in Different Provinces of Saudi Arabia. J Trop Pediatr. 2002;48(3):172-177. doi: 10.1093/tropej/48.3.172. [PubMed] [Cross Ref]

[16]. Huang TT, Harris KJ, Lee RE, Nazir N, Born W, Kaur H. Assessing Overweight, Obesity, Diet, and Physical Activity in College Students. J Am Coll Health. 2003;52(2):83-86. doi: 10.1080/07448480309595728. [PubMed] [Cross Ref]

[17]. World Health Organization. Obesity: preventing and managing the global epidemic. Report of a WHO consultation. World Health Organ Tech Rep Ser. 2000;894:1-253. http://whqlibdoc.who.int/trs/WHO_TRS_894.pdf (accessed September 1, 2010)[PubMed]

[18]. Rasheed P, Abou-Hozaifa BM, Kahn A. Obesity among young Saudi female adults: a prevalence study on medical and nursing students. Public Health. 1994;108(4):289-294. doi: 10.1016/S0033-3506(94)80008-1. [PubMed] [Cross Ref]

[19]. Abdel-Megeid et al.Nutritional habits and Cardio-vascular diseases in university students. Saudi Med J.2011; 32(6): 621-27.

[20]. Al-Hazzaa HM, Abahussain N, Al-Sobayel H, Qahwaji D, Musaiger AO.(Physical Activity, Sedentary Behaviors and Dietary Habits among Saudi Adolescents Relative to Age, Gender and Region. Int J Behav Nutr Phys Act. 2011;2(8):140.

[21]. Davis AM, Boles RE, James RL, Sullivan DK, Donnelly JE, Swirczynski DL,Goetz J. Health behaviors and weight status among urban and rural children. Rural Remote Health. 2008; 8(2):810.

[22]. Rampersaud GC, Pereira MA, Girard BL, Adams J, Metzl JD: Breakfast habits,nutritional status, body weight, and academic performance in children and adolescents. J Am Diet Assoc. 2005;105:743-760.

[23]. Al-Hazzaa HM: Physical activity, fitness and fatness among Saudi children and adolescents: implications for cardiovascular health. Saudi Med J.2002;23:144-150.

[24]. Al-Hazzaa H: Prevalence of physical inactivity in Saudi Arabia: a brief review.East Mediterr Health J. 2004;10:663-670.

[25]. Al-Nuaim AA, Al-Nakeeb Y, Lyons M. Al-Hazzaa HM, Nevill A, Collins P,Duncan MJ. The prevalence of physical activity and sedentary behaviors relative to obesity among adolescents from Al-Ahsa, Saudi Arabia: Rural versus urban variations. J of Nutr and Metabol. 2012;:Article ID 417589, doi:10.1155/2012/417589. 